\title{
Eksistensi Fatwa Majelis Ulama Indonesia Dalam Perspektif Negara Hukum Pancasila
}

\author{
Slamet Suhartono \\ (Fakultas Hukum Universitas 17 Agustus 1945 Surabaya, Email: slamet@untag- \\ sby.ac.id)
}

\begin{abstract}
Abstrak:
Berdasarkan Pasal 1 angka 2, Pasal 7 ayat (1) dan Pasal 8 ayat (1) UU 12/2011, fatwa MUI bukan peraturan perundang-undangan, karena tidak dibuat oleh badan/atau lembaga yang berwenang dan tidak memiliki kekuatan mengikat umum. Namun, fatwa MUI merupakan sumber hukum materiil. Untuk menjadi hukum positif, maka fatwa MUI harus dipositivisasi oleh negara melalui peraturan perundangundangan. Sebagai sumber hukum materiil, Fatwa MUI dapat dijadikan sebagai rujukan pembentukan peraturan perundangundangan, bahkan menjadi rujukan wajib. Pasal 26 ayat (3) UU 21/2008 mewajibkan Peraturan Bank Indonesia menuangkan fatwa MUI tentang prinsip syariah, Pasal 25 UU 19/2008 mewajibkan Menteri Keuangan untuk meminta fatwa MUI sebagai dasar penerbitan SBSN, dan Pasal II angka 1 huruf a UU 1/2011 menjadikan fatwa MUI sebagai dasar atau acuan bagi penyeleng garaan kontrak derivatif syariah. Dengan demikian, fatwa MUI seolah-olah mengikat dalam hal dikeluarkan berdasarkan perintah dari peraturan perundang-undangan.
\end{abstract}

\section{Kata Kunci :}

Fatwa, Majelis Ulama Indonesia, Peraturan Perundang-Undangan.

\begin{abstract}
:
According to the first verse of paragraph 2, verse 7 (1) and verse 8 (1) of Law 12/2011, MUI is not legislation, because it was not made by the body / or national authorities and do not have a common binding force. However, the MUI fatwa is a legal source material. To become a positive law, the MUI should be positive by the state through legislation. As a source of substantive law, the MUI Fatwa or statement can be used as a reference formation of legislation, even become a mandatory referral. verse 26 paragraph (3) of Law 21/2008 requires that Bank of Indonesia has regulation to pour MUI fatwa on Islamic principles, verse 25 of Law 19/2008 requires that the Minister
\end{abstract}

al-1hkam Vol.12 No.2 Desember 2017

DOI 10.19105/al-ihkam.v12i2.1255 
of Finance to ask the MUI for issuing SBSN, and verse II item 1 letter an of Law 1/2011 makes MUI as a basis or reference for conducting sharia derivative contracts. Thus, the MUI fatwa or statement as though binding in the case was issued by the command of the legislation.)

\section{Keyword :}

Fatwa, the Indonesian Ulema Council, Regulation Legislation

\section{Pendahuluan}

Pada masa awal orde baru, ketika terjadi kemunduran politik, pemerintah menggagas berdirinya wadah perkumpulan ulama se nusantara agar dapat membatasi gerak umat islam di Indonesia. Tanggal 7 Rajab tahun 1395 Hijriah atau tanggal 26 Juli tahun 1975 dibentuklah sebuah organisasi yang menjadi wadah perkumpulan para ulama yang kemudian diberi nama Majelis Ulama Indonesia (MUI). Organisasi yang dibentuk oleh pemerintah orde baru tersebut menjadi rumah bagi para ulama, cendekiawan muslim dan zu'ama yang berasal dari seluruh penjuru tanah air.

Selaras dengan pernyataan di atas, Azumardi Azra mengemukakan, bahwa: "Majelis Ulama Indonesia adalah organisasi keagamaan yang bersifat independen, tidak berafiliasi kepada salah satu partai politik, mazhab atau aliran keagamaan islam yang ada di Indonesia". ${ }^{1}$ Oleh karena itu, MUI sebagai sebagai organisasi keagamaan yang independen menurut Muhammad Atho Mudzhar mempunyai fungsi-fungsi sebagai berikut: (1) sebagai pewaris tugas-tugas para nabi (Warasatul Anbiya); (2) sebagai pemberi fatwa (Mufti); (3) sebagai pembimbing dan pelayan umat (Ri'ayat wa khaim al ummah); (4)sebagi gerakan Islah wa al Tajdid; dan (5) sebagai penegak amar ma'ruf nahi munkar. ${ }^{2}$

Berdasarkan fungsi-fungsi tersebut, yang paling menonjol dan berpengaruh terhadap kehidupan berbangsa dan bernegara khususnya bagi umat Islam adalah fungsi MUI sebagai pemberi fatwa

\footnotetext{
${ }^{1}$ Azumardi Azra, Menuju Masyarakat Madani: Gagasan, Fakta dan Tanggapan, Cetakan ke I, Rosdakarya, Bandung, 2000, 65.

${ }^{2}$ Muhammad Atho Mudzhar, Fatwa-Fatwa Majelis Ulama Indonesia: Sebuah Studi Tentang Pemikiran Hukum Islam di Indonesia 1975-1988, INIS, Jakarta, 1993, 63.
} 
(Mufti). Sebab, hal tersebut dapat dijadikan dasar dalam setiap tindakan baik bagi umat muslim di Indonesia maupun bagi pemerintah dalam hal menetapkan kebijakan yang berkaitan dengan hukum islam (syari'ah). Sebab bagaimanapun juga Indonesia sebagai negara yang mayoritas penduduknya beragama Islam atau muslim, sehingga setiap kebijakan yang diambil oleh pemerintah harus memperhatikan nilai-nilai keislaman.

Kewenangan MUI sebagai pemberi fatwa tidak terlepas dari fungsi MUI yang ditentukan dalam Pasal 4 Anggaran Dasar dan Anggaran Rumah Tangga (AD/ART) MUI, yakni sebagai berikut Majelis Ulama Indonesia berfungsi: Pertama Sebagai wadah musyawarah para ulama, zu'ama dan cendekiawan muslim dalam mengayomi umat dan mengembangkan kehidupan yang Islami, Kedua Sebagai wadah silaturrahmi para ulama, zu'ama dan cendekiawan muslim untuk mengembangkan dan mengamalkan ajaran Islam dan menggalang ukhuwah Islamiyah, Ketiga Sebagai wadah yang mewakili umat Islam dalam hubungan dan konsultasi antar umat beragama, dan Keempat Sebagai pemberi fatwa kepada umat Islam dan pemerintah, baik diminta maupun tidak diminta.

Berdasarkan ketentuan di atas, jelas bahwa MUI dapat memberikan fatwa yang ditujukan secara khusus kepada umat Islam maupun pemerintah dalam urusan yang berkaitan dengan umat Islam, baik diminta maupun tidak diminta. Artinya bahwa, fatwa MUI tersebut dapat dikeluarkan, karena diminta oleh umat Islam maupun pemerintah atau karena terkait dengan permasalahan atau peristiwa konkrit yang memerlukan jawaban yang musykil secara syari'at atau hukum Islam. Sebagai contoh mengenai persoalan haram, halal atau makruh terhadap rokok yang beberapa waktu yang lalu menjadi permasalahan bagi masyarakat muslim di Indonesia.

Dalam menjalankan fungsinya sebagai pemberi fatwa (mufti), MUI telah mengeluarkan beberapa fatwa yang berkaitan dengan hukum Islam. Fatwa MUI tersebut dikeluarkan, baik yang terkait dengan 'ubudiyah maupun muammalah. Tidak jarang fatwa MUI menimbulkan kontroversi dan polemik di tengah-tengah bermasyarakat. Iswahyudi menyatakan bahwa:

“...MUI belum maksimal dalam menjalankan fungsinya sebagai organisasi yang inklusif dalam masalah fatwa keagamaan yang diproduksinya. Fatwa MUI justru tampak memiliki kecenderungan eksklusif. Melalui fatwanya, 
MUI memosisikan diri sebagai hakim keyakinan seseorang atau kelompok.. MUI menyesatkan sebuah paham, MUI melarang perkembangan suatu pendapat keagamaan dan MUI mendorong pemerintah untuk membubarkan paham, pendapat dan aliran...".3

Bahkan fatwa MUI juga sering menimbulkan perdebatan di kalangan umat Islam sendiri, karena disebabkan oleh berbagai faktor seperti mazhab, keilmuan dan faktor-faktor lainnya. Terakhir, pada tahun 2016 MUI mengeluarkan 2 (dua) fatwa yang banyak menuai polemik, yakni fatwa (sikap keagamaan) untuk menyikapi pidato Basuki Tjahaja Purnama atas kasus penistaan Surat Al-Maidah ayat 51 dan fatwa mengenai hukum mengenakan atribut keagamaan nonmuslim. Kedua fatwa tersebut juga tidak luput dari berbegai perdebatan dan silang pendapat antara ahli dengan berbagai perspektif masing-masing. Di kalangan umat islam sendiri juga banyak yang mempertanyakan kedua fatwa tersebut, karena perbedaan penafsiran yang didasarkan atas pandangan atau persepsi masing-masing, serta madzab atau aliran yang dianutnya, dan alasan lain yang diyakini kebenarannya. Namun di sisi yang lain, secara sosiologis fatwa MUI dibutuhkan oleh umat Islam di Indonesia sebagai pendapat alim ulama terhadap suatu perkara tertentu. Bahkan secara yuridis, pemerintah membutuhkan fatwa MUI karena diwajibkan dalam peraturan perundang-undangan.

Berdasarkan uraian fakta-fakta di atas, kiranya fatwa-fatwa yang dikeluarkan oleh MUI tersebut menarik untuk dikaji secara mendalam melalui optik hukum tata negara. Terlebih, fatwa MUI seringkali dijadikan dasar oleh umat Islam daripada peraturan perundang-undangan itu sendiri. Oleh karena itu, dalam tulisan ini dibatasi untuk membahas mengenai kedudukan dan peran fatwa MUI dalam sistem hukum Indonesia. Oleh karena itu, untuk mempertegas kedudukan dan peran fatwa MUI dalam sistem hukum nasional, secara akademik diajukan pertanyaan sebagai berikut: Bagaimana eksistensi fatwa MUI dalam perspektif Negara Hukum Pancasila?

\footnotetext{
${ }^{3}$ Iswahyudi, Majelis Ulama Indonesia dan Nalar Fatwa-Fatwa Eksklusif, Jurnal Al-
} Hikam: Jurnal Hukum dan Pranata Sosial, Vol.11, No.2 Desember 2016, 363-365. 


\section{Metode Penelitian}

Penulisan ini merupakan penelitian hukum yang berobjekan substansi hukum Islam, yaitu suatu proses untuk menemukan aturan hukum, prinsip-prinsip hukum, maupun doktrin-doktrin hukum guna menjawab isu hukum yang dihadapi. ${ }^{4}$ Dalam menjawab isu hukum yang diajukan dalam penulisan ini, digunakan 2 (dua) pendekatan, yaitu pendekatan perundang-undangan (statute approach) dan pendekatan konseptual (conceptual approach).

Pendekatan perundang-undangan (statute approach), yaitu menggunakan peraturan perundang-undangan yang berkaitan dengan eksistensi fatwa MUI dalam perspektif negara hukum Pancasila, meliputi Undang-undang Nomor 19 Tahun 2008 tentang Surat Berharga Syariah Negara; Undang-undang Nomor 21 Tahun 2008 tentang Perbankan Syariah; Undang-undang Nomor 10 Tahun 2011 tentang Perubahan Atas Undang-undang Nomor 32 Tahun 1997 tentang Perdagangan Berjangka Komoditi; dan Undang-undang Nomor 12 Tahun 2011 tentang Pembentukan Peraturan Perundang Undangan. Selain itu, dalam penulisan ini juga digunakan pendekatan konseptual (conceptual approach), yaitu mengelaborasi konsep-konsep hukum yang berkaitan dengan eksistensi fatwa MUI dalam perspektif negara hukum Pancasila guna memecahkan atau menjawab isu hukum atau permasalahan yang ada. ${ }^{5}$

\section{Pembahasan}

Secara etimologi (lughawi), kata fatwa berasal dari bahasa arab al-Fatwa. Menurut Ibnu Mandzur, kata fatwa merupakan bentuk mashdar dari kata fata, yaftu, fatwan, yang bermakna muda, baru penjelasan, penerangan. ${ }^{6}$ Paralel dengan pendapat tersebut, alFayumi sebagaimana dikutip oleh Ma'ruf Amin mengemukakan bahwa, "al-fatwa berasal dari kata al-fata, artinya pemuda yang kuat". ${ }^{7}$ Sehingga, orang yang mengeluarkan fatwa dikatakan sebagai mufti,

4 Peter Mahmud Marzuki, Penelitian Hukum (legal research), Prenada Media, Jakarta, 2005, 35.

${ }^{5}$ Ibid, 93.

${ }^{6}$ Ibnu Mandzur, Lisan al-Arab - Juz XV, Dar Shadir, Beirut, 145.

${ }^{7}$ Ma'ruf Amin, Fatwa Dalam Sistem Hukum Islam, Paramuda Advertising, Jakarta, 2008, 19. 
karena orang tersebut diyakini mempunyai kekuatan dalam memberikan penjelasan dan jawaban terhadap permasalahan yang dihadapinya sebagai kekuatan yang dimiliki oleh seorang pemuda. Berbeda dengan hal tersebut, menurut al-Jurjani, "fatwa berasal dari al-fata atau al-futya, artinya jawaban terhadap suatu permasalahan dalam bidang hukum, sehingga fatwa dalam pengertian ini diartikan sebagai memberikan penjelasan" .8

Dalam Kamus Besar Bahasa Indonesia, fatwa didefinsikan sebagai "jawab" (keputusan, pendapat) yang diberikan oleh mufti tentang suatu masalah. Arti lain dari fatwa menurut Kamus Besar Bahasa Indonesia adalah "nasihat orang alim", "pelajaran baik", "petuah". 9 Sedangkan secara terminologi (syar'i), as-Syatibi menjelaskan bahwa, "fatwa dalam arti al-ifta berarti keteranganketerangan tentang hukum syara' yang tidak mengikat untuk diikuti.10 Selanjutnya, menurut Yusuf Qardawi, "fatwa adalah menerangkan hukum syara' dalam suatu persoalan sebagai jawaban atas pertanyaan yang diajukan oleh peminta fatwa baik secara perseorangan maupun kolektif". ${ }^{11}$ Selaras dengan pendapat Yusuf Qardlawy, Zamakhsyari sebagaimana dikutip oleh Ma'ruf Amin menyatakan bahwa, "fatwa adalah penjelasan hukum syara' tentang suatu masalah atas pertanyaan seseorang atau kelompok. ${ }^{12}$ Senada dengan hal tersebut, Murtadho Ridwan menyatakan bahwa fatwa merupakan hasil ijtihad ulama yang sangat mendalam untuk menyelesaikan masalah-masalah yang dihadapi masyarakat. ${ }^{13}$

Berdasarkan penjelasan di atas, ada 2 (dua) hal penting yang harus digaris bawahi, pertama bahwa fatwa bersifat responsif, sebab pertama, fatwa merupakan jawaban atau pendapat hukum (legal opinion) atas pertanyaan atau permintaan fatwa (based on demand);

\footnotetext{
${ }^{8}$ Ibid.

${ }^{9}$ Departemen Pendidikan Nasional, Kamus Besar Bahasa Indonesia, Balai Pustaka, Jakarta, 2003,. 314

${ }^{10} \mathrm{Abu}$ Ishaq Ibrahim ibn Mas'ud al-Syatibi, alMuwafaqat fi Ushuli al-Ahkam - Juz $I V$, Dar al-Rasyad al-Haditsah, Beirut,. 141

${ }^{11}$ Yusuf Qardlawy, al-Fatwa bain al-Indlibath wa al-Tasayyub, Dar al-Qalam, Mesir,. 5

${ }^{12}$ Ma'ruf Amin, Op.Cit. 20

${ }^{13}$ Murtadho Ridwan, Analisis Penyerapan Fatwa DSN-MUI Tentang Asuransi Syariah Ke Dalam PSAK 108, Jurnal ADDIN, Vol. 8 No. 1 Februari 2014,.136
} 
kedua, fatwa sebagai jawaban hukum yang bersifat tidak mengikat, dengan kata lain, orang yang meminta fatwa baik perseorangan, lembaga, maupun masyarakat tidak harus mengikuti fatwa atau hukum yang diberikan kepadanya. Dengan demikian, fatwa selalu berhubungan dengan persoalan yang terjadi dan perlu jawaban secara hukum atas persoalan tersebut. Sehingga, fatwa seringkali berkaitan dengan peristiwa konkret. Niki Alma Febriana Fauzi menyatakan bahwa fatwa merupakan jawaban resmi atas 1) pertanyaan atau 2) persoalan penting menyangkut dogma atau hukum yang diberikan oleh orang yang mempunyai otoritas. Fatwa menjadi bagian yang sangat penting dalam kehidupan sosial keagamaan. Fatwa juga menjadi legitimasi atas praktik sosialekonomi baru yang tidak terdapat secara ekspilisit aturan bakunya dalam al-Quran dan Sunah. ${ }^{14}$

Selanjutnya, berkenaan dengan eksistensi fatwa MUI dalam perspektif negara hukum Pancasila, muncul pertanyaan mendasar, yaitu apakah fatwa MUI merupakan hukum positif ${ }^{15}$ atau bukan. Dengan kata lain apakah fatwa MUI merupakan bagian dari peraturan perundang-undangan. Untuk menjawab hal tersebut, maka Pasal 1 angka 2 Undang-Undang Nomor 12 Tahun 2012 tentang Pembentukan Peraturan Perundang-Undangan dapat dijadikan rujukan, karena di dalam pasal tersebut telah ditentukan unsur-unsur dari peraturan peraturan perundang-undangan atau hukum positif.

Pasal 1 angka 2 Undang-Undang Nomor 12 Tahun 2011 Tentang Pembentukan Peraturan Perundang-Undangan, menentukan bahwa: "Peraturan perundang-undangan adalah peraturan tertulis yang memuat norma hukum yang mengikat secara umum dan dibentuk

\footnotetext{
${ }^{14}$ Niki Alma Febriana Fauzi, Fatwa di Indonesia:Perubahan Sosial, Perkembangan dan Keberagaman, Jurnal Hukum Novelty, Vol.8, No.1 Februari 2017. 109-110 ${ }^{15}$ Istilah hukum positif (ius positiva) lahir dari mazhab positivisme yang dikemukakan oleh John Austin. Mazhab positivisme menyatakan bahwa yang dikatakan hukum adalah perintah penguasa, sehingga aturan yang berlaku berdasarkan adat kebiasaan tidak dapat dikatakan sebagai "hukum". Sehingga, "hukum positif adalah hukum yang dibuat oleh penguasa yang berdaulat". Di kalangan ahli hukum, juga banyak kekeliruan dalam mendefinisikan hukum positif sebagai hukum yang berlaku di suatu tempat dan waktu tertentu. Jika demikian pengertiannya, maka hukum adat juga masuk dalam pengertian hukum positif karena berlaku di tengah-tengah masyarakat.
} 
atau ditetapkan oleh lembaga negara atau pejabat yang berwenang melalui prosedur yang ditetapkan dalam Peraturan Perundangundangan." Mendasarkan ketentuan pasal tersebut, maka suatu aturan dapat dikatatakan sebagai peraturan perundang-undangan apabila 1) tertulis; 2) memuat norma hukum berupa perintah, larangan, izin dispensasi, kewenangan dan sebagainya; 3) mengikat secara umum; 4) dibentuk atau ditetapkan oleh pejabat yang berwenang, dimana kewenangan tersebut merupakan kewenangan yang dijamin baik oleh Undang-Undang Dasar Negara Republik Indonesia Tahun 1945 maupun undang-undang; dan 5) dibentuk melalui prosedur yang diatur di dalam peraturan perundangundangan. Unsur-unsur tersebut bersifat kumulatif, sehingga suatu aturan dapat dikatakan sebagai peraturan perundang-undangan apabila memenuhi kelima unsur tersebut.

Selain secara normatif yuridis sebagaimana telah dijelaskan di atas, dalam doktrin juga dikembangkan beberapa kriteria atau unsur suatu aturan dapat disebut sebagai peraturan perundang-undangan. Sebagaimana dikatakan Bagir Manan dengan menyatakan bahwa: Untuk disebut sebagai peraturan perundang-undangan maka harus memenuhi unsur sebagai berikut: pertama Peraturan perundangundangan berbentuk keputusan tertulis. Karena merupakan keputusan tertulis, peraturan perundang-undangan sebagai kaidah hukum tertulis (geschrevenrecht, written law); Kedua Peraturan perundang-undangan dibentuk oleh pejabat atau lingkungan jabatan (badan, organ) yang mempunyai wewenang membuat "peraturan" yang berlaku atau mengikat umum (algemeen); dan Ketiga Peraturan perundang-undangan bersifat mengikat umum, tidak dimaksudkan harus selalu mengikat semua orang. Mengikat umum hanya menunjukkan bahwa Peraturan perundang-undangan tidak berlaku terhadap peristiwa konkret atau individu tertentu ${ }^{16}$.

Senada dengan pendapat Bagir Manan di atas, Maria Farida Indrati Soeprapto juga menyatakan bahwa: Istilah perundangundangan (legislation, wetgeving, atau gezetzgebbung) mempunyai dua

\footnotetext{
${ }^{16}$ Mahendra Kurniawan, dkk., Pedoman Naskah Akdemik PERDA Partisipatif Cetakan ke I, Kreasi Total Media, Yogyakarta, 2007. hlm. 5
} 
pengertian: Pertama Perundang-undangan merupakan proses pembentukan/proses memben tuk peraturan-peraturan Negara, baik tingkat pusat maupun ditingkat daerah, Kedua Perundang-undangan adalah segala peraturan Negara, yang merupakan hasil pembentukan peraturan-peraturan, baik ditingkat pusat maupun di tingkat daerah. ${ }^{17}$

Berdasarkan penjelasan di atas, maka selanjutnya perlu dianalisis, apakah fatwa MUI memenuhi unsur-unsur yang ada dalam Pasal 1 angka 2 Undang-undang Nomor 12 Tahun 2011 tentang Pembentukan Peraturan Perundang Undangan. Pertama, apakah fatwa MUI tertulis, tentu jawabannya adalah tertulis; kedua, apakah fatwa MUI memuat norma hukum, jawabannya adalah fatwa MUI memuat norma hukum, namun berisi norma hukum agama, bukan norma hukum dalam pengertian sesungguhnya; ketiga, apakah fatwa MUI mengikat secara umum, jawabannya adalah bahwa fatwa MUI tidak memiliki kekuataan mengikat secara hukum (rechtgeldig) artinya bahwa fatwa MUI tidak dapat dipaksakan kepada masyarakat muslim dan masyarakat muslim tidak dapat dikenakan sanksi karena ketidak patuhan terhadap fatwa MUI. Penegak hukum, apakah Polisi, Jaksa atau Hakim tidak dapat menggunakan fatwa MUI untuk menjadikan seorang tersangka, menuntut ke depan pengadilan atau menjatuhkan hukuman. Untuk itu, maka fatwa MUI hanya mempunyai kekuatan mengikat secara moral (moral binding). Orang tunduk dan patuh terhadap fatwa MUI lebih pada keyakinannya, bahwa apa yang difatwakan tersebut memiliki unsur kebenaran dalam perspektif keislaman; keempat, apakah MUI pejabat dan/atau badan yang berwenang untuk membentuk perundang-undangan, jawabanyannya adalah MUI bukan lembaga negara yang diberikan kewenangan untuk membentuk peraturan perundang-undangan, baik oleh Undang-Undang-Undang Dasar Negara Republik Indonesia Tahun 1945, maupun oleh undang-undang; kelima, apakah fatwa MUI dibentuk melalui prosedur yang telah ditentukan dalam peraturan perundang-undangan, jawabannya adalah prosedur pembentukan fatwa MUI tidak diatur di dalam peraturan perundang-undangan,

\footnotetext{
${ }^{17}$ Maria Farida Indrati Soeprapto, Ilmu Perundang-Undangan: Jenis, Fungsi, dan Materi Muatan (Buku 1), Kanisius, Yogyakarta, 2007, 3.
} 
yakni Undang-Undang Nomor 12 Tahun 2011 tentang Pembentukan Peraturan Perundang-Undangan. Fatwa MUI dibentuk sesuai dengan prosedur yang ada dan berlaku dalam MUI itu sendiri.

Berdasarkan analisis dan uraian di atas, maka fatwa MUI tidak memenuhi kelima unsur atau kriteria peraturan perundangundangan. Untuk itu, fatwa MUI tidak dapat dikategorikan sebagai peraturan perundang-undangan. Hal utama yang menjadi landasan berfikir penulis adalah karena fatwa MUI tidak dibuat oleh pejabat dan/atau badan yang berwenang dan tidak mempunyai kekuatan mengikat umum. Fatwa MUI hanya sebagai pendapat mufti yang diberikan kepada pihak yang meminta fatwa (mustaftin), baik perorangan maupun lembaga yang tidak bersifat mengikat, kecuali diperintahkan oleh peraturan perundang-undangan yang berlaku. Fatwa MUI dalam hal ini tidak lebih sebagaimana halnya doktrin atau pendapat ahli (professional opinion) yang dalam litelatur ilmu hukum digolongkan ke dalam sumber hukum yang tidak mengikat (nonbinding sources of law). Terkait dengan hal tersebut,

“...MUI adalah organisasi Alim Ulama Umat Islam yang mempunyai tugas dan fungsi untuk pemberdayaan masyarakat/umat Islam, artinya MUI adalah organisasi yang ada dalam masyarakat, dan bukan merupakan institusi milik negara atau merepresentasikan negara. Artinya pula, fatwa MUI bukanlah hukum negara yang mempunyai kedaulatan yang bisa dipaksakan bagi seluruh rakyat, fatwa MUI juga tidak mempunyai sanksi dan tidak harus ditaati oleh seluruh warga negara. Sebagai sebuah kekuatan sosial politik yang ada dalam infra struktur ketatanegaraan, Fatwa MUI hanya mengikat dan ditaati oleh komunitas umat Islam yang merasa mempunyai ikatan terhadap MUI itu sendiri. Legalitas fatwa MUI pun tidak bisa dan mampu memaksa harus ditaati oleh seluruh umat Islam". 18

Selain itu, fatwa MUI tidak masuk dalam kategori peraturan perundang-undangan, dikarenakan fatwa MUI tidak memenuhi persyaratan kekuatan berlaku sebagai peraturan perundang-

\footnotetext{
${ }^{18}$ Ainun Najib, Fatwa Majelis Ulama Indonesia Dalam Perspektif Pembangunan Hukum Responsif, Jurnal Lisan Al-Hal, Volume 4, Nomor 2 Desember 2012, 374375.
} 
undangan. Padahal, menurut Sudikno Mertokusumo untuk dikatakan peraturan perundang-undangan harus memiliki 3 (tiga) aspek kekuatan, yakni kekuatan yuridis (juristische geltung), kekuatan sosiologis (soziologische geltung) dan kekuatan filosofis (filosofische geltung). Selengkapnya Sudikno Mertokusumo, mengemukakan:

Peraturan perundang-undangan mempunyai persyaratan untuk dapat berlaku atau mempunyai kekuatan berlaku. Ada tiga macam kekuatan berlaku, yaitu kekuatan berlaku yuridis, sosiologis dan filosofis. Berdasarkan ketiga kriteria kekuatan berlakunya hukum tersebut, fatwa MUI hanya mempunyai kekuatan berlaku sosiologis, yaitu khusus bagi umat Islam yang meminta secara kolektif. Namun tidak mempunyai kekuatan secara yuridis karena tidak memenuhi prosedur formal pembentukan peraturan perundang-undangan dan tidak mempunyai kekuatan keberlakuan secara filosofis karena dalam penyusunannya didasarkan pada hukum Islam (syari'ah), bukan pada nilai-nilai Pancasila. Di samping itu, juga tidak memenuhi keberlakuan yuridis karena bukan merupakan produk hukum yang tergolong norma hukum positif. Penulis berpendapat bahwa fatwa MUI hanya memiliki kekuatan mengikat secara moral (moral binding), sehingga keberlakuannya apakah itu ditaati atau dilanggar sangat bergantung kepada keyakinan dan kepercayaan masing-masing umat islam. Untuk itu, fatwa MUI tidak dapat ditegakkan sebagaimana penegakan hukum terhadap peraturan perundang-undangan. ${ }^{19}$

Selanjutnya, tidak diakuinya fatwa MUI sebagai peraturan perundang-undangan juga dikuatkan dengan ketentuan Pasal 7 ayat (1) dan Pasal 8 ayat (1) Undang-Undang Nomor 12 Tahun 2011 tentang Pembentukan Peraturan Perundang Undangan yang menentukan sebagai berikut: Pasal 7 (1) Jenis dan hierarki Peraturan Perundang-undangan terdiri atas: (a) UndangUndang Dasar Negara Republik Indonesia Tahun 1945; (b) Ketetapan Majelis Permusyawaratan Rakyat; (c) UndangUndang/Peraturan Pemerintah Pengganti Undang-Undang; (d) Peraturan Pemerintah; (e) Peraturan Presiden; (f) Peraturan Daerah Provinsi; dan (g) Peraturan Daerah Kabupaten/Kota.

\footnotetext{
${ }^{19}$ Sudikno Mertokusumo, Mengenal Hukum: Suatu Pengantar, Liberty, Yogyakarta, 1999, 87-88.
} 
Dalam Pasal 8 ayat (1) Jenis Peraturan Perundang-undangan selain sebagaimana dimaksud dalam Pasal 7 ayat (1) mencakup peraturan yang ditetapkan oleh Majelis Permusyawaratan Rakyat, Dewan Perwakilan Rakyat, Dewan Perwakilan Daerah, Mahkamah Agung, Mahkamah Konstitusi, Badan Pemeriksa Keuangan, Komisi Yudisial, Bank Indonesia, Menteri, badan, lembaga, atau komisi yang setingkat yang dibentuk dengan Undang-Undang atau Pemerintah atas perintah UndangUndang, Dewan Perwakilan Rakyat Daerah Provinsi, Gubernur, Dewan Perwakilan Rakyat Daerah Kabupaten/Kota, Bupati/Walikota, Kepala Desa atau yang setingkat.

Merujuk pada ketentuan di atas, jelas bahwa baik Pasal 7 ayat (1) maupun Pasal 8 ayat (1) Undang-Undang Nomor 12 Tahun 2011 tentang Pembentukan Peraturan Perundang Undangan tidak mengenal istilah fatwa MUI sebagai salah satu jenis peraturan perundang-undangan yang berlaku di Indonesia. Artinya bahwa, oleh karena fatwa MUI bukan merupakan peraturan perundang-undangan yang berlaku di Indonesia, maka secara otomatis keberadaannya tidak dikategorikan pula sebagai hukum positif. Soleh hasan wahid menyatakan bahwa:

"berdasarkan Pasal 7 dan 8 di atas, fatwa tidak termasuk salah satu jenis peraturan perundang-undangan yang diatur dalam Undang-Undang. Oleh karena itu ia tidak bisa berlaku secara serta merta. Fatwa baru bisa diimplementasikan oleh lembaga perbankan syariah apabila sudah dipositifikasikan menjadi hukum positif...Dengan dituangkannya Fatwa DSN-MUI ke dalam Peraturan Bank Indonesia, maka kekuatannya tidak hanya mengikat secara moral tapi juga mengikat secara hukum".20

Menurut penulis, fatwa MUI lebih tepat disebut sebagai sumber hukum dalam arti materiil. Sebagai sumber hukum materiil memiliki fungsi dan peran penting dalam pembentukan hukum positif atau hukum perundang-undangan di Indonesia, dengan mengingat

\footnotetext{
${ }^{20}$ Soleh Hasan Wahid, Pola Transformasi Fatwa Ekonomi Syariah DSN-MUI dalam Peraturan Perundang-Undangan Indonesia, Jurnal Ahkam, Volume 4, Nomor 2 November 2016, 174.
} 
mayoritas masyarakat Indonesia yang beragama Islam (muslim). Hal tersebut tercermin dari ketentuan Pasal 26 ayat (2) dan ayat (3) Undang-undang Nomor 21 Tahun 2008 tentang Perbankan Syariah, yang menentukan sebagai berikut: Pertama Kegiatan usaha sebagaimana dimaksud dalam Pasal 19, Pasal 20, dan Pasal 21 dan/atau produk dan jasa syariah, wajib tunduk kepada Prinsip Syariah. Kedua Prinsip Syariah sebagaimana dimaksud pada ayat (1) difatwakan oleh Majelis Ulama Indonesia. Ketiga Fatwa sebagaimana dimaksud pada ayat (2) dituangkan dalam Peraturan Bank Indonesia. Keempat Dalam rangka penyusunan Peraturan Bank Indonesia sebagaimana dimaksud pada ayat (3), Bank Indonesia membentuk komite perbankan syariah. Dan Kelima Ketentuan lebih lanjut mengenai tata cara pembentukan, keanggotaan, dan tugas komite perbankan syariah sebagaimana dimaksud pada ayat (4) diatur dengan Peraturan Bank Indonesia.

Merujuk pada ketentuan tersebut di atas, jelas bahwa Pasal 26 ayat (2) Undang-undang Nomor 21 Tahun 2008 tentang Perbankan Syariah, menyebutkan bahwa fatwa MUI untuk menentukan prinsipprinsip syariah produk perbankan syariah. Hal tersebut memperkuat pendapat Penulis bahwa fatwa MUI merupakan sumber hukum dalam arti materil untuk Peraturan Bank Indonesia dan bersifat tidak mengikat. Supaya fatwa MUI tersebut mengikat, maka Pasal 26 ayat (3) menentukan, bahwa fatwa MUI tersebut harus dituangkan ke dalam Peraturan Bank Indonesia. Dengan kata lain, bahwa fatwa MUI tersebut bukan merupakan peraturan perundang-undangan sebelum dipositivisasi menjadi peraturan Bank Indonesia, yang menurut Pasal 8 ayat (1) Undang-Undang Nomor 12 Tahun 2011 tentang Pembentukan Peraturan Perundang-Undangan, dikategorikan sebagai peraturan perundang-undangan. Artinya bahwa, fatwa MUI dapat menjadi hukum positif apabila ada kehendak negara, yang dalam hal ini adalah Peraturan Bank Indonesia. Hal tersebut menandakan bahwa fatwa MUI tidak dapat berdiri sendiri untuk menjadi hukum positif, namun dibutuhkan kemauan negara untuk menjadikannya sebagai instrumen hukum dalam bentuk peraturan perundang-undangan. 
Terkait dengan hal tersebut, Ahyar Ari Gayo dan Ade Irawan Taufik menyatakan bahwa:

“...sebagai pihak regulator kegiatan perbankan syariah, Bank Indonesia, juga mempunyai keterikatan dengan Fatwa yang dihasilkan oleh DSN-MUI. Dalam membuat Peraturan Bank Indonesia, Bank Indonesia menggunakan Fatwa DSN-MUI sebagai bahan referensi dalam penyusunan Peraturan Bank Indonesia dan juga Surat Edaran yang bersifat eksternal. Dalam praktek pembuatan PBI terkait dengan perbankan syariah Bank Indonesia hanya boleh merujuk Fatwa DSN-MUI dalam menyusun PBI, dan tidak merujuk pada fatwa yang dikeluarkan oleh institusi selain DSN-MUI. Apabila melihat kedudukan fatwa DSN-MUI yang terdapat dalam peraturan perundang-undangan, maka fatwa DSN-MUI merupakan perangkat aturan kehidupan masyarakat yang bersifat mengikat bagi Bank Indonesia sebagai regulator, yaitu adanya kewajiban agar materi muatan yang terkandung dalam Fatwa MUI dapat diserap dan ditransformasikan dalam merumuskan prinsip-prinsip syariah dalam bidang perbankan syariah menjadi materi muatan Peraturan Perundangundangan yang memiliki kekuatan hukum dan mengikat umum...".21

Di samping itu, Pasal 25 Undang-Undang Nomor 19 Tahun 2008 tentang Surat Berharga Syariah Negara, menentukan, “Dalam rangka penerbitan SBSN, Menteri meminta fatwa atau pernyataan kesesuaian SBSN terhadap prinsip-prinsip syariah dari lembaga yang memiliki kewenangan dalam penetapan fatwa di bidang syariah." Lebih lanjut, penjelasan Pasal 25 Undang-Undang Nomor 19 Tahun 2008 tentang Surat Berharga Syariah Negara tersebut menjelaskan, "Yang dimaksud dengan "lembaga yang memiliki kewenangan dalam menetapkan fatwa di bidang syariah" adalah Majelis Ulama Indonesia atau lembaga lain yang ditunjuk Pemerintah."

\footnotetext{
${ }^{21}$ Ahyar Ari Gayo dan Ade Irawan Taufik, Kedudukan Fatwa Dewan Syarian Nasional Majelis Ulama Indonesia Dalam Mendorong Perkembangan Bisnis Perbankan Syariah (Perspektif Perbankan Syariah, Jurnal Rechtvinding: Media Pembinaan Hukum Nasional, Volume 1 Nomor 2 Agustus 2012, 267-268.
} 
Memperhatikan ketentuan Pasal 25 Undang-Undang Nomor 19 Tahun 2008 tentang Surat Berharga Syariah Negara, berikut penjelasannya sebagaimana diuraikan di atas, secara hukum fatwa MUI diakui di dalam peraturan perundang-undangan, yakni sebagai dasar atau rujukan atas penerbitan Surat Berharga Syariah Negara, guna menyesuaikan dengan prinsip-prinsip syariah. Adapun fatwa MUI tersebut dijadikan dasar dalam penerbitan Surat Berharga Syariah Negara, karena MUI merupakan lembaga yang berwenang mengeluarkan fatwa yang berkaitan dengan prinsip-prinsip hukum Islam (syari'ah). Dengan demikian, keberadaan fatwa MUI dianggap penting bagi penerbitan Surat Berharga Syariah Negara yang dilakukan oleh Menteri Keuangan. Sebab, jika penerbitan tersebut tidak didasarkan pada fatwa MUI, maka akan berdampak pada keabsahan Surat Berharga Syariah Negara. Oleh karena itu, fatwa MUI mengikat secara tidak langsung bagi Menteri yang hendak menerbitkan Surat Berharga Syariah Negara.

Namun demikian, daya mengikat fatwa MUI terhadap Menteri yang berwenang menerbitkan Surat Berharga Syariah Negara tersebut tidak serta merta menjadikan fatwa MUI sebagai dasar hukum yang masuk dalam kategori peraturan perundang-undangan. Sebab untuk dikatakan peraturan perundang-undangan, harus dibentuk oleh pejabat yang berwenang dan bersifat mengikat umum sebagaimana disyaratkan dalam Undang-Undang Nomor 12 Tahun 2011 Tenang Pembentukan Peraturan Perundang-undangan.

Selain beberapa ketentuan sebagaimana telah dijelaskan tersebut di atas, Pasal II angka 1 huruf a Undang-Undang Nomor 10 Tahun 2011 tentang Perubahan Atas Undang-undang Nomor 32 Tahun 1997 tentang Perdagangan Berjangka Komoditi menentukan, "Sebelum dibentuknya Peraturan perundang-undangan yang mengatur tentang perdagangan berjangka komoditi syariah, maka penyelenggaraan Kontrak Derivatif Syariah ditetapkan berdasarkan Fatwa Dewan Syariah Nasional - Majelis Ulama Indonesia". Mengacu pada ketentuan tersebut, keberadaan fatwa MUI sangat penting, karena dijadikan dasar atau acuan bagi penyelenggaraan kontrak derivatif syariah. Dengan demikian, fatwa MUI mempunyai kekuatan mengikat dalam penyelenggaraan kontrak derivatif syariah di Indonesia. 


\section{Penutup}

Berdasarkan uraian penjelasan di atas, disimpulkan bahwa keberadaan fatwa MUI di Indonesia sangat penting bagi penyelenggaraan kehidupan berbangsa dan bernegara, khususnya dalam konteks pembangunan sistem hukum berbasis syari'ah. Hal tersebut tercermin dari beberapa ketentuan peraturan perundangundangan yang masih menjadikan fatwa MUI sebagai rujukan. Bahkan, tanpa fatwa MUI tersebut, sebuah penyelenggaraan pemerintahan dapat dipermasalahkan keabsahannya, karena cacat secara prosedur. Cacat prosedur yang demikian sebagaimana diatur dalam Undang-Undang Nomor 19 Tahun 2008 tentang Surat Berharga Syariah Negara, yang menempatkan fatwa MUI sebagai dasar penerbitan SBSN oleh Menteri Keuangan.

Demikian pula dengan Undang-undang Nomor 10 Tahun 2011 tentang Perubahan Atas Undang-undang Nomor 32 Tahun 1997 tentang Perdagangan Berjangka Komoditi yang menentukan, bahwa penyelenggaraan kontrak derivatif syariah harus merujuk pada fatwa Dewan Syariah Nasional MUI. Tidak hanya itu, peraturan Bank Indonesia yang berkaitan dengan urusan syariah pun wajib mengacu pada fatwa MUI. Dengan demikian, fatwa MUI seolah-olah mengikat dalam hal dikeluarkan berdasarkan perintah dari peraturan perundang-undangan.

Meskipun fatwa MUI mempunyai daya ikat, hal itu sematamata karena diperintahkan oleh peraturan perundang-undangan, bukan karena fatwa MUI berkedudukan sebagai peraturan perundang-undangan. Sebab fatwa MUI tidak memenuhi unsur sebagai peraturan perundang-undangan. Di mana, fatwa MUI tersebut tidak bersifat mengikat umum (erga omnes), dan tidak dibuat oleh lembaga yang berwenang menetapkan peraturan perundangundangan. Oleh karena itu, menurut hukum fatwa MUI bukan merupakan peraturan perundang-undangan, yang berarti pula bahwa fatwa MUI tidak termasuk dalam kategori hukum positif. Namun demikian, fatwa MUI dapat digolongkan sebagai sumber hukum materiil dan sumber hukum yang tidak mengikat (non binding sources of law). 


\section{Daftar Pustaka}

Abu Ishaq Ibrahim ibn Mas'ud al-Syatibi, alMuwafaqat fi Ushuli alAhkam - Juz IV, Dar al-Rasyad al-Haditsah, Beirut.

Ahyar Ari Gayo dan Ade Irawan Taufik, Kedudukan Fatwa Dewan Syarian Nasional Majelis Ulama Indonesia Dalam Mendorong Perkembangan Bisnis Perbankan Syariah (Perspektif Perbankan Syariah, Jurnal Rechtvinding: Media Pembinaan Hukum Nasional, Volume 1 Nomor 2, Agustus 2012.

Ainun Najib, Fatwa Majelis Ulama Indonesia Dalam Perspektif Pembangunan Hukum Responsif, Jurnal Lisan Al-Hal, Volume 4, Nomor 2, Desember 2012.

Azumardi Azra, Menuju Masyarakat Madani: Gagasan, Fakta dan Tanggapan, Cetakan ke I, Rosdakarya, Bandung, 2000.

Departemen Pendidikan Nasional, Kamus Besar Bahasa Indonesia, Balai Pustaka, Jakarta, 2003.

Ibnu Mandzur, Lisan al-Arab - Juz XV, Dar Shadir, Beirut.

Iswahyudi, Majelis Ulama Indonesia dan Nalar Fatwa-Fatwa Eksklusif, Jurnal Al-Hikam: Jurnal Hukum dan Pranata Sosial, Vol.11, No.2 Desember 2016.

Ma'ruf Amin, Fatwa Dalam Sistem Hukum Islam, Paramuda Advertising, Jakarta, 2008.

Mahendra Kurniawan, dkk., Pedoman Naskah Akdemik PERDA Partisipatif - Cetakan ke I, Kreasi Total Media, Yogyakarta, 2007.

Maria Farida Indrati Soeprapto, Ilmu Perundang-Undangan: Jenis, Fungsi, dan Materi Muatan (Buku 1), Kanisius, Yogyakarta, 2007.

Muhammad Atho Mudzhar, Fatwa-Fatwa Majelis Ulama Indonesia: Sebuah Studi Tentang Pemikiran Hukum Islam di Indonesia 19751988, INIS, Jakarta, 1993.

Murtadho Ridwan, Analisis Penyerapan Fatwa DSN-MUI Tentang Asuransi Syariah Ke Dalam PSAK 108, Jurnal ADDIN, Vol. 8 No. 1 Februari 2014.

Niki Alma Febriana Fauzi, Fatwa di Indonesia:Perubahan Sosial, Perkembangan dan Keberagaman, Jurnal Hukum Novelty, Vol.8, No.1 Februari 2017. 
Peter Mahmud Marzuki, Penelitian Hukum (legal research), Prenada Media, Jakarta, 2005.

Soleh Hasan Wahid, Pola Transformasi Fatwa Ekonomi Syariah DSNMUI Dalam Peraturan Perundang-Undangan Indonesia, Jurnal Ahkam, Volume 4, Nomor 2, November 2016.

Sudikno Mertokusumo, Mengenal Hukum: Suatu Pengantar, Liberty, Yogyakarta, 1999.

Undang Undang Dasar Negara Kesatuan Republik Indonesia Tahun 1945.

Undang-Undang Nomor 10 Tahun 2011 tentang Perubahan Atas Undang-undang Nomor 32 Tahun 1997 tentang Perdagangan Berjangka Komoditi.

Undang-Undang Nomor 12 Tahun 2011 Tenang Pembentukan Peraturan Perundang-undangan.

Undang-Undang Nomor 19 Tahun 2008 tentang Surat Berharga Syariah Negara

Undang-undang Nomor 21 Tahun 2008 tentang Perbankan Syariah

Undang-undang Nomor 32 Tahun 1997 tentang Perdagangan Berjangka Komoditi.

Yusuf Qardlawy, al-Fatwa bain al-Indlibath wa al-Tasayyub, Dar alQalam, Mesir. 